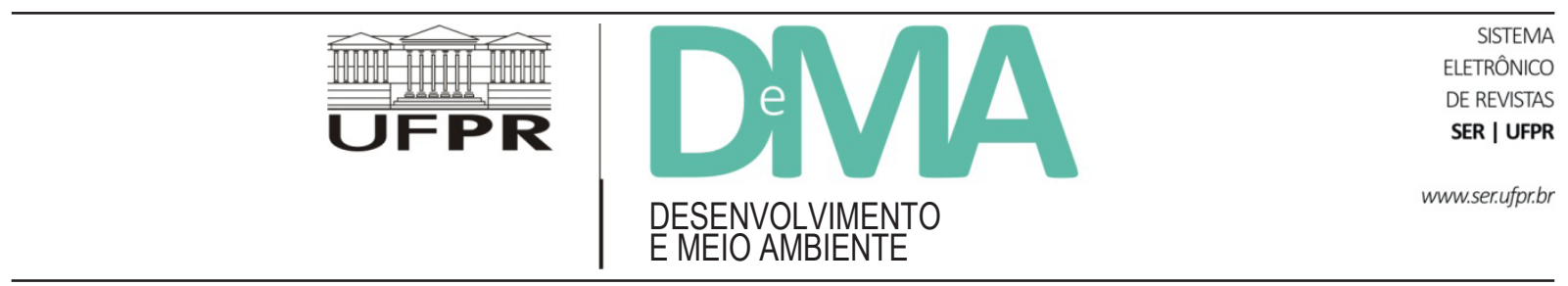

\title{
Não há peixe para pescar neste verão: efeitos socioambientais durante a construção de grandes barragens - o caso Belo Monte
}

\section{There is no Fish to Catch This Summer: Reflections on Environmental Effects during the Construction of Large Dams - the Belo Monte Case}

\author{
Sonia Barbosa MAGALHÃES ${ }^{1 *}$, Ygor Yuri Pereira da SILVA ${ }^{1}$, Cleice da Luz VIDAL ${ }^{2}$ \\ ${ }^{1}$ Núcleo de Ciências Agrárias e Desenvolvimento Rural, Universidade Federal do Pará (UFPA), Belém, PA, Brasil. \\ ${ }^{2}$ Programa de Pós-Graduação em Agriculturas Amazônicas, Universidade Federal do Pará (UFPA), Belém, PA, Brasil. \\ *E-mail de contato: smag@ufpa.br
}

Artigo recebido em 29 de fevereiro de 2016, versão final aceita em 28 de abril de 2016.

RESUMO: A maioria dos estudos de cunho socioantropológico que versa sobre os efeitos socioambientais decorrentes da construção de grandes barragens dedica-se aos fenômenos que se verificam após o barramento do rio. Neste texto, a partir de pesquisa de campo realizada no contexto de construção de Belo Monte, pretendemos evidenciar como, do ponto de vista de quem os vivencia, os efeitos socioambientais do período pré-operação não são negligenciáveis e nem meramente transitórios. Durante a construção, o fluxo de máquinas, equipamentos e pessoas destinados à construção e seu entorno incide sobre territórios e recursos naturais que são condição para a reprodução social e econômica de povos e comunidades. O conhecimento tradicional acumulado faculta a apreensão de transformações sutis no ambiente, incluindo o comportamento de peixes e demais integrantes da fauna aquática, alterações na turbidez da água, na vegetação e outras, assim como mudanças nas relações sociais, incluindo restrições ao deslocamento de pessoas e de objetos. O gradiente de sua magnitude não pode estar fora do contexto no qual ocorre. Deveria ter como unidade de medida o sentido vivido. Dos pontos de vista institucional e político, é necessário que haja reconhecimento da epistemologia de produção e reprodução do conhecimento tradicional, com canais competentes para que as avaliações produzidas a partir dele sejam igualmente consideradas.

Palavras-chave: barragem; Belo Monte; pescadores; efeitos ambientais.

ABSTRACT: Most anthropological studies do not analyzes the environmental effects of the construction of large dams. In this text, from field research conducted in the Belo Monte construction context, we intend to show how, from the point of view of those who experience them, the social and environmental effects of the pre-operation period are not negligible or merely temporary. During construction, the flow of machines, equipment and personnel for the construction site and its surroundings focus on territories and natural resources that are condition for social 
and economic reproduction of people and communities. The accumulated traditional knowledge provides the seizure of subtle changes in the environment, including fish behavior and other components of the aquatic fauna, changes in water turbidity, vegetation and other, as well as changes in social relations, including restrictions on the movement of people and objects. The gradient magnitude can not be out of the context in which it occurs. Should have as unit of measurement the lived sense. Institutionally and politically there must be recognition of the epistemology of production and reproduction of traditional knowledge, with appropriate channels so that the evaluations produced from it are also considered.

Keywords: dam; Belo Monte; fishermen; environmental effects.

\section{Introdução}

Pode-se afirmar que a maioria dos estudos de cunho socioantropológico que versa sobre os efeitos socioambientais decorrentes da construção de grandes barragens dedica-se aos fenômenos que se verificam após o barramento do rio, notadamente aqueles referentes ao deslocamento compulsório de grupos sociais e às transformações no território e suas consequências (Magalhães, 2007; Magalhães \& Sanz, 2015). Salvo estudos que tratam sobre temas como emprego, migração, reprodução da força de trabalho (e similares), não temos conhecimento de títulos que tratem especificamente sobre efeitos socioambientais que incidem sobre o modo de viver, a produção e a reprodução dos grupos sociais locais durante a construção da barragem. Um dos trabalhos mais amplos sobre impactos de barragens, como aquele produzido pela Comissão Mundial de Barragens (WCD, 2000), também não faz referência ao período de construção.

A frase que dá título a este trabalho é inspirada em observações realizadas por pescadores/moradores da Volta Grande do Xingu, onde está sendo construído o complexo Hidrelétrico Belo Monte, que desde 2012 vêm sistematicamente denunciando alterações que se verificaram no comportamento do rio e da fauna aquática que incidem diretamente sobre o seu modo de viver e sobre a sua principal atividade econômica - a pesca. A frase foi proferida em julho, verão amazônico de 2015.
Neste texto, a partir de pesquisa de campo realizada durante a construção de Belo Monte, pretendemos evidenciar como, do ponto de vista de quem os vivencia, os efeitos socioambientais do período pré-operação não são negligenciáveis e nem meramente transitórios. Ao contrário, até antecipam efeitos que, no entanto, na literatura sobre o tema somente são mencionados a posteriori. Referimo-nos especificamente aos efeitos sobre o modo de viver de pescadores e suas famílias que habitam e trabalham em territórios submetidos ao fluxo de máquinas, equipamentos e pessoas destinados à construção e em seu entorno. Este modo de viver, em consonância com o saber acumulado a respeito do comportamento do rio, dos peixes e demais integrantes da fauna e da flora aquáticas, é assolado por esta modalidade de desorganização socioambiental que, por sua vez, precede a transformação do rio em lago - e após esta se agudiza.

Do ponto de vista sociotécnico e político, considerar esses efeitos (e sua magnitude) significa alargar o conceito e o campo da desestruturação ambiental e das perdas imputadas a estas populações humanas e não humanas, relativizando o seu caráter transitório e incorporando um custo social e econômico geralmente desconsiderado.

No caso de Belo Monte, os pescadores que habitavam no trecho do Rio Xingu que se estende aproximadamente da cidade de Altamira até a localidade denominada Vila Nova, no município 
de Vitória do Xingu, desde 2012 observam e vivenciam transformações socioambientais que incidem sobre os berçários de reprodução de peixes, sobre o modo de viver dos peixes adultos, sobre as vias de navegação e pontos de pesca, sobre a vegetação das margens do rio, de suas ilhas e de micro-habitats específicos e, enfim, sobre o estoque do pescado - base de sua dieta e de sua inserção no mercado. Trata-se de pescadores artesanais, isto é, pescadores cujas relações de produção, por um lado, estão ancoradas no trabalho familiar, no parentesco, na vizinhança e em regras de prestação e de contraprestação revestidas sob a forma de dádiva (Mauss, 1997), e, por outro, no conhecimento acumulado e permanentemente reconstruído sobre o ambiente aquático e suas relações (Diegues, 1983) e sobre instrumentos de trabalho apropriados, que se acumulam por gerações. No atual arcabouço jurídico-político nacional, integram o conjunto denominado "Povos Tradicionais" (Decreto 6.040, de 07 de fevereiro de 2007).

Este artigo está estruturado do seguinte modo: após a apresentação do local e das principais técnicas de pesquisa, explana-se sobre as modalidades de pescaria existentes na Volta Grande do Xingu. A seguir, com base no relato dos pescadores, expomos as principais consequências advindas da construção das usinas e os termos da controvérsia entre pescadores e a empresa responsável pela obra, seguidos das considerações finais.

\section{Caminhos e locus da pesquisa}

Este estudo está baseado em pesquisa de cunho socioantropológico que vem sendo desenvolvida desde 2011. A última etapa de coleta de dados voltada para o tema aqui discutido foi realizada entre maio e agosto de 2015 e concentrada em duas localidades, Ressaca e Ilha da Fazenda, situadas no trecho denominado Volta Grande do Xingu - VGX (Figura 1).

Foram realizadas vinte e duas entrevistas semiestruturadas, além de observação direta e conversas informais com pescadores ${ }^{1}$, homens e mulheres. Além deste trecho, foram realizadas visitas, acompanhadas por pescadores, ao trecho do rio localizado à jusante de Belo Monte, no qual também há relatos sobre dificuldades e escassez similares, ambos os trechos localizados no município de Vitória do Xingu.

Ilha da Fazenda e Ressaca são duas localidades situadas na Volta Grande do Xingu, com população aproximada de 220 habitantes. A maioria das famílias é resultante de casamentos intra e interétnicos, principalmente entre as etnias Juruna, $\mathrm{Xi}$ paya, Kuruaya e Arara, além de brancos. As águas do rio servem de transporte, para a pesca (principal atividade econômica), lazer e atividades domésticas, como lavagem de roupas e utensílios. Apesar da presença de poços, alguns moradores também utilizam a água do rio Xingu para o consumo. Os pescadores entrevistados, com idades entre 25 e 83 anos e em média com mais de 20 anos pescando no rio Xingu, são reconhecidos localmente como pescadores experientes, detentores de conhecimentos sobre a pesca artesanal e foram identificados pelo método bola de neve (Bernard, 2002). Além dos pescadores, foram entrevistados presidentes das colônias de pescadores, integrantes do movimento social "Xingu vivo para sempre", para onde é canalizada boa parte das denúncias acumuladas.

\footnotetext{
1 Esta etapa de pesquisa de campo resultou em monografia apresentada em nível de Pós-Graduação lato sensu. Ver Silva (2015).
} 


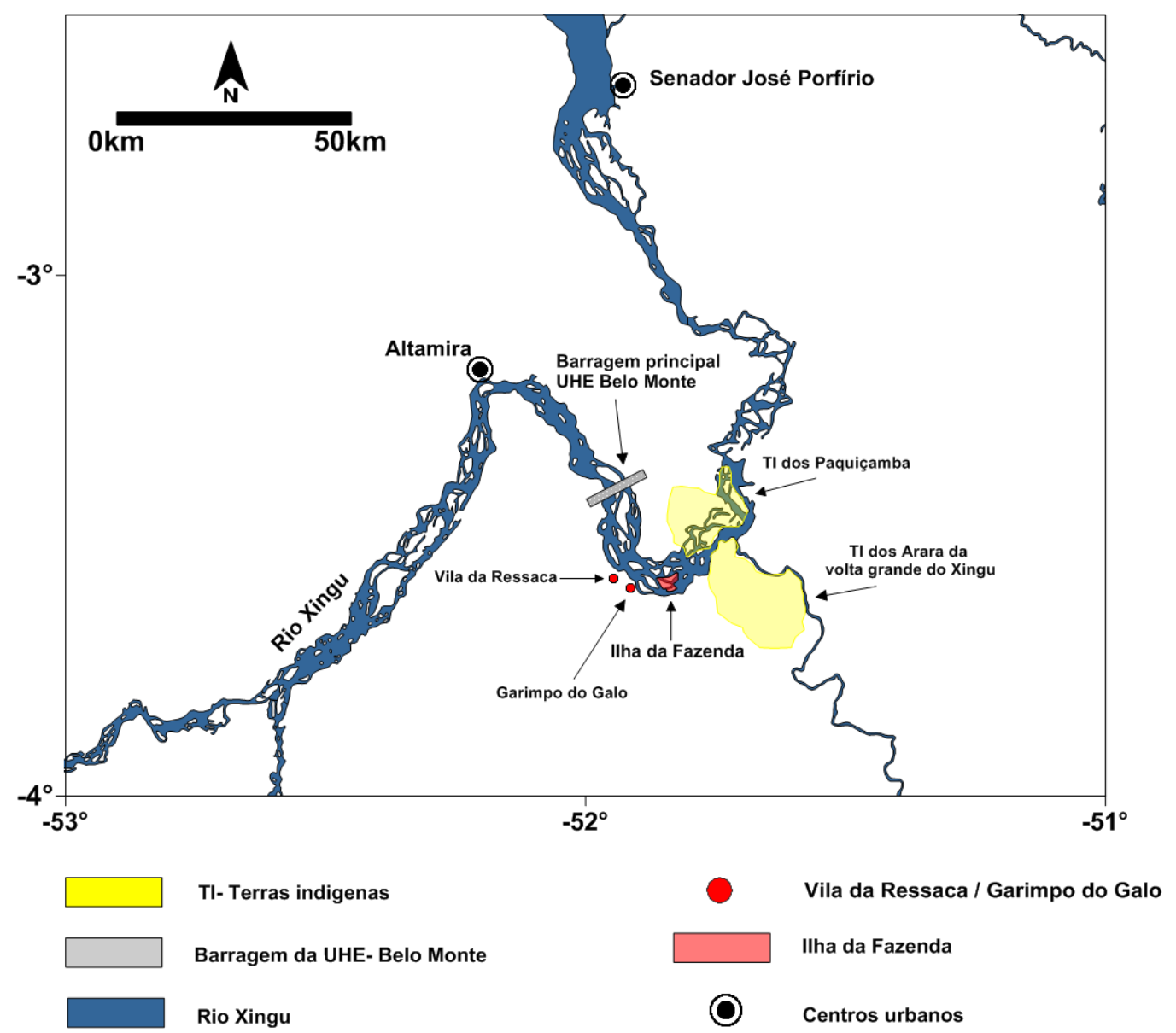

FIGURA 1 - Volta Grande do Xingu.

FONTE: Elaborado por Gomes, V. Laboratório de Geologia Costeira, UFPA, campus Bragança.

\subsection{A Volta Grande do Xingu}

A bacia hidrográfica do rio Xingu abrange $520.292 \mathrm{~km}^{2}$, onde predominam formações rochosas cristalinas do complexo Xingu. As nascentes do rio estão situadas a mais de $600 \mathrm{~m}$ de altitude e são delimitadas por serras. O relevo e o clima são essenciais para os processos de denudação, decomposição, transporte e sedimentação, existente ao longo de todo o Xingu (Camargo \& Ghilardi Jr.,
2009). O clima da área é quente e úmido do tipo Amw' (segundo o sistema de classificação climática de Köppen), caracterizado por um período chuvoso, entre os meses de dezembro e maio, e um período seco, nos demais meses do ano (Sudam, 1995).

A Volta Grande do Xingu (VGX), com aproximadamente duzentos quilômetros de extensão, faz parte da fall line zone (zona de linha de queda) sul amazônica (Ab'Sáber, 1996). De acordo com Medeiros (2009, p. 167), o longo trecho encachoeirado 
que a compõe configura-se "como uma importante barreira geográfica" que divide a Bacia do Xingu em três regiões: da nascente até a Volta Grande; a Volta Grande; e desde esta até a foz do rio, no Amazonas. Trata-se de uma área densa e diversificada, composta por rios e seus afluentes, igarapés, lagos, furos, igapós e uma floresta primária com madeiras de lei raras, além de espécies endêmicas. É habitada por povos de diversas etnias, aldeados e não aldeados, especialmente Xipaia, Kuruaia, Kayapó, além das etnias Juruna e Arara, cujas terras estão situadas quase confrontes: TI Paquiçamba - de ocupação imemorial da etnia Juruna, na margem esquerda do rio Xingu, e a TI Arara da Volta Grande do Xingu, na margem direita, de ocupação imemorial dos índios da etnia Arara.

A usina de Belo Monte, capacidade instalada de $11.233,1 \mathrm{MW}$, começou a ser construída em 2010, entrou em operação em abril de 2016 e conta com duas barragens: uma em Altamira, usina do sítio Pimental, no início do trecho encachoeirado em desnível que se estende por toda a Volta Grande, e outra em Vitória do Xingu, usina do sítio Belo Monte, ao fim do trecho encachoeirado. O barramento do sítio Pimental redireciona a vazão principal do rio para um canal de $20 \mathrm{~km}$ de comprimento, que conduzirá a água desviada até diques que abastecerão a geração no sítio Belo Monte. Seguirá pela Volta Grande apenas um resíduo da vazão original que, conforme previsto, se estenderá ao longo do ano entre um mínimo de $700 \mathrm{~m}^{3} / \mathrm{s}$ nos meses de seca até $4.000 \mathrm{~m}^{3} / \mathrm{s}$ na cheia - para os anos classificados na série histórica como secos - ou de $700 \mathrm{~m}^{3} / \mathrm{s}$ na seca até $8.000 \mathrm{~m}^{3} / \mathrm{s}$ na cheia - para os anos classificados na série histórica como cheios (Molina, 2009), sabendo que a vazão natural varia em média de 1.125 $\mathrm{m}^{3} / \mathrm{s}$ a $22.744 \mathrm{~m}^{3} / \mathrm{s}$. Desta decisão técnica de realizar o semidesvio do rio resultam efeitos específicos de Belo Monte, dentre os quais: defasagem de cerca de
$60 \%$ entre a capacidade instalada e a energia firme; suspensão da navegação; e, conforme observa Sevá (2005, p. 195), "uma situação inédita para todos os seres vivos", que passarão a viver uma espécie de verão permanente, com a criticidade da seca, antes evento extremo, tornada cíclica.

\section{A pesca na Volta Grande do Xingu}

Existem dois tipos de pescarias, classificadas pelos próprios pescadores da VGX, e as duas são artesanais. Uma delas, a ornamental, hoje tem um grande mercado consumidor nacional e internacional. Nos rios Xingu e Tapajós, bem como no Tocantins e no Trombetas, encontram-se os mais importantes portos de desembarque de peixes ornamentais da família Loricariidae (acaris) e de outros grupos, como as arraias (Potamotrygonidae) e os acarás (Cichlidae) (Camargo, Carvalho Jr. \& Estupiñan, 2012). Nestes sistemas existem catalogadas, respectivamente, 422 e 410 espécies de peixes com interesse ornamental (Carvalho Júnior, 2008).

Dentre as espécies de maior importância destacam-se o endêmico Acari zebra (Hypancistrus zebra) e os abundantes Amarelinho (Baryancistrus xanthellus) (Figura 2) e o Picota ouro (Scobinancistrus aureatus).

Os pescadores de espécies ornamentais são localmente denominados acarizeiros e trabalham individualmente ou em pequenos grupos. Destacam-se entre estes os índios Juruna.

Esta modalidade de pesca é geralmente realizada por meio de mergulhos livres ou usando compressores de ar (Figura 3), que possibilitam maiores tempos debaixo d'água e assim maior produtividade, mas os riscos são maiores também, como relata um ex-acarizeiro: 


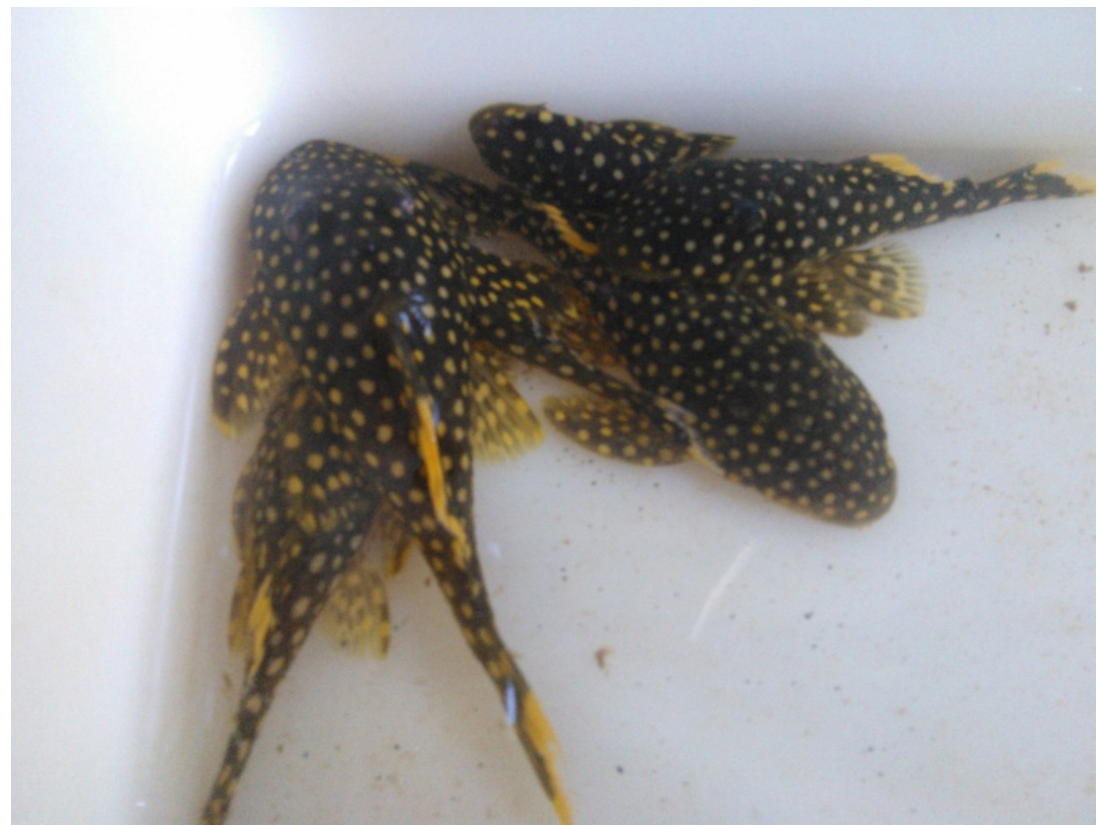

FIGURA 2 - Peixe ornamental Amarelinho, Baryancistrus xanthellus. FONTE: Trabalho de campo, 2015. Foto Yuri Silva.

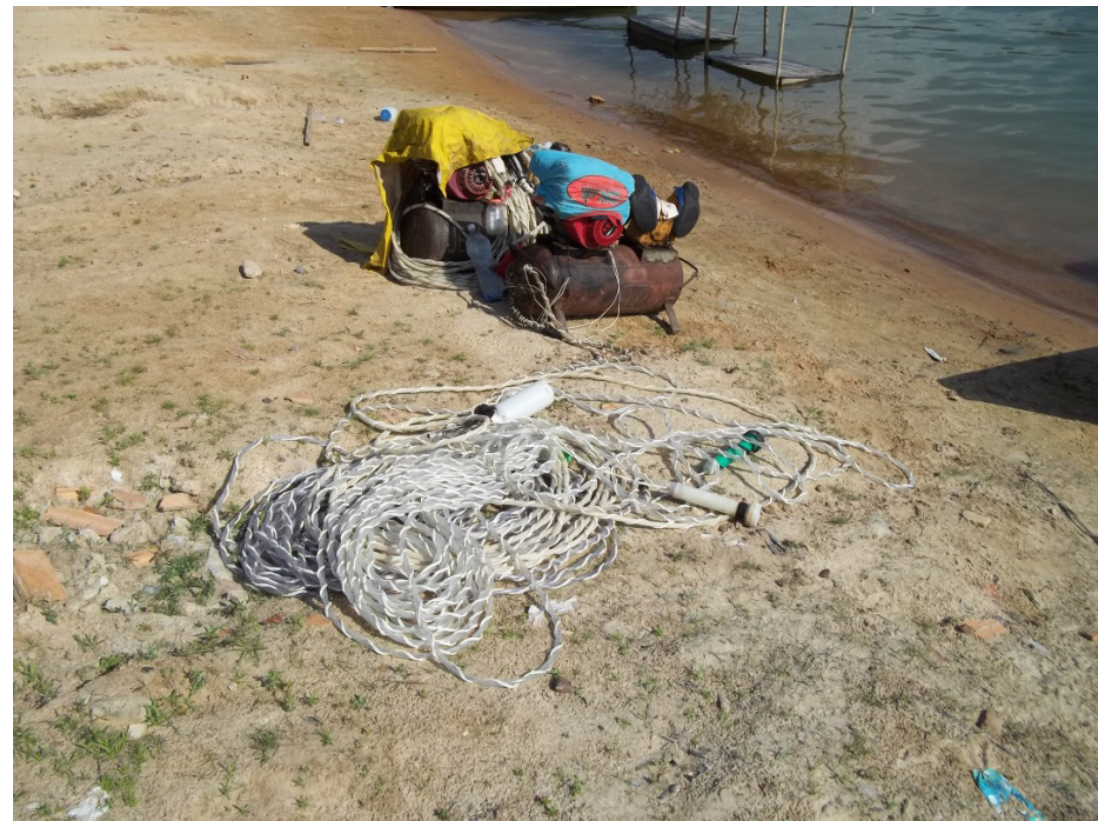

FIGURA 3 - Compressor de ar utilizado na pescaria ornamental. FONTE: Trabalho de campo, 2015. Foto Yuri Silva. 
[...] eu tava na pescaria, pescando ornamental e o mangueiro enganchou e a chupeta sacou da minha boca e eu tive um momento dificil na minha vida. Consegui, Deus me ajudou a voltar pra cima, bebi muita água, passei mal pra caramba, mas consegui graças a Deus. (C, pescador, 31 anos)

A outra modalidade de pescaria é a de consumo e/ou comercial (Figura 4), realizada em locais com no máximo 3 a 4 horas de viagem, com canoas a remo ou rabetas com motor de popa, exercida por grupos familiares ou pescadores individuais. Tem como preferência os tucunarés (Cichla spp), os pacus (Myloplus e Myleus spp), matrinxã (Brycon $s p p$ ), como definido entre os próprios pescadores. Alguns destes pacus somente são encontrados na VGX, as chamadas espécies endêmicas, como o pacu seringa (Myleus rhomboidolis) e o pacu capivara (Ossubtus xinguensis).

Os pescadores não indígenas entrevistados chegaram à região por volta da década de 1940 com o boom da mineração de ouro, atividade que se iniciava e era promissora. Após o garimpo ser comprado e fechado, a atividade principal passou a ser a pesca.

Independente de qual seja a modalidade de pescaria, envolve homens e mulheres, em grupo, ou em dupla que pode ser composta pelo marido e a esposa, ou apenas sozinhos, cada um em seu "casco". Utiliza-se de um conhecimento construído, dinâmico, resultado de observação, raciocínio, especulação, intuição e saberes ancestrais repassados através da oralidade e da experimentação. Um saber

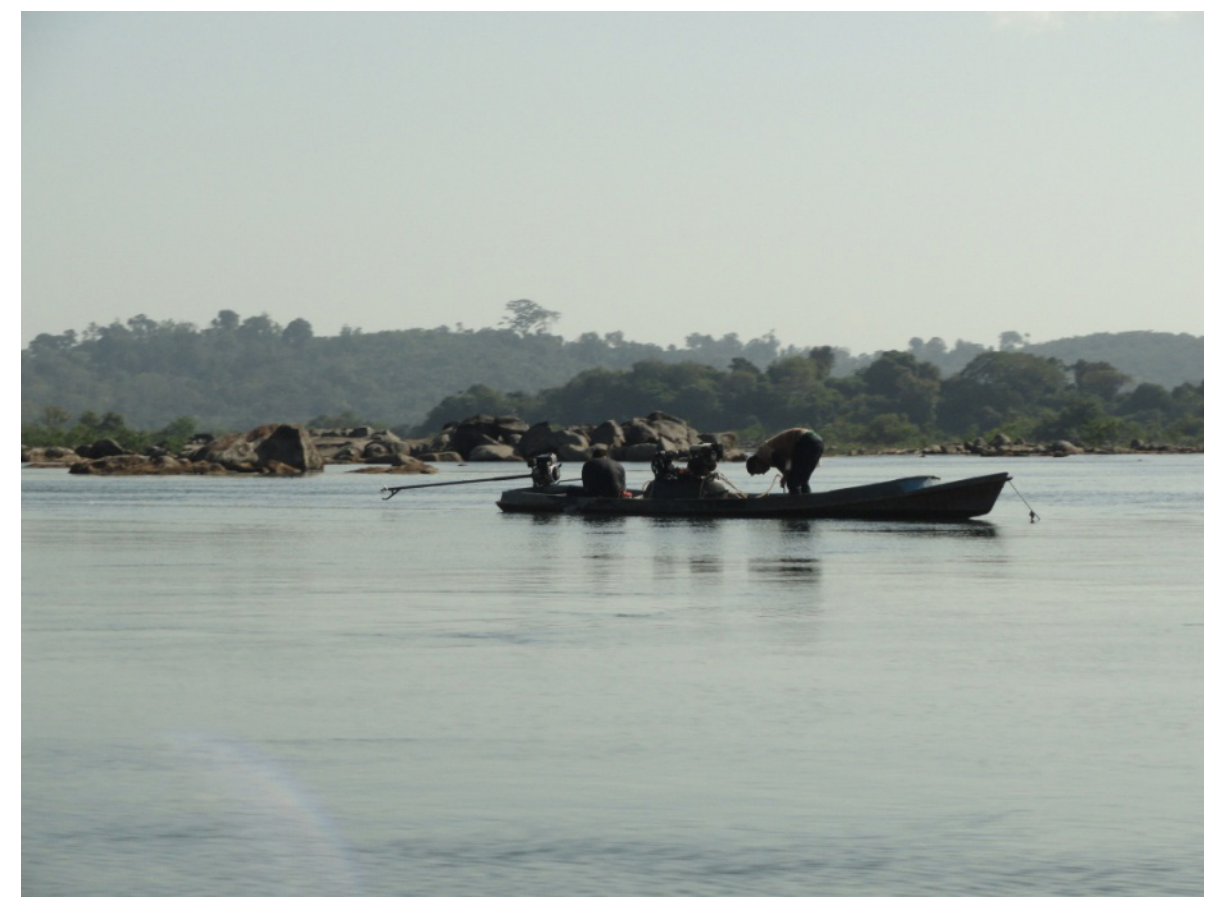

FIGURA 4 - Pescadores artesanais da Volta Grande do Xingu. FONTE: Trabalho de campo, 2015. Foto Yuri Silva. 
incorporado e constitutivo de um modo de viver que se expressa em frases como "Ah porque a gente já é juramentado naquilo já (na pescaria)".

Perguntados sobre como aprenderam todo o conhecimento, sobre o local de cada peixe, os locais de pesca, apetrechos de pesca, como se marisca, movimento da água, qual peixe é aquele e desde quando pescam, são todos incisivos: pescam desde criança, nasceram e se criaram pescando, observando ou experimentando a arte de pescar com pais, avós, tios, amigos e conhecidos:

Olha, desde pequeno, que eu me entendo por gente, eu vejo meu pai. Meu pai era um cara que ele pescava muito, ele gostava de pescar, mas mais era só por esporte entende. Ele gostava. Ai, e com isso eu fui aprendendo. (S., pescador, 33 anos)

Ah eu comecei acho que me criei praticamente dentro de uma canoa mais meu pai, quando me entendi de gente já andava mais meu pai-desde 5 anos. (Pescadora, mulher de S., 36 anos)

[...] acho que o primeiro dia que pesquei ainda era um pouco criança... peixinho mesmo de telinha que eu peguei ainda era adolescente, criança assim criada em beira do rio, dificil de dizer assim... Com теи pai que era pescador também. (R., pescadora, 43 anos)

[...] completei 10 anos, aí meu colega lá era até o Zezinho de Belém, ai foi e me chamou e disse "Pedrinho bora pescar?" eu digo "meu amigo eu vou não". Ai foi, sentei até no porão desses "caxiris" que a pessoa chama canoa né, pra lá (Ceará) pra nós chama "caxiri". Ai eu fui e embarquei, mas eu pegava no casco desse jeito assim (gestos de segurar) e eu ficava com medo. Ai depois foi quando eu completei os 12 anos, já eu fui operacionalizando, pescando com eles, quando eu saí de Belém eu tava com 15 anos já e eu sabia (pescar). (P., pescador, 64 anos)
Os pais relatam sobre o interesse e o prazer das crianças em participar da pescaria, neste caso considerada como brincadeira, mas uma etapa fundamental para a aquisição de um saber e a conformação de um modo de viver:

Meu filho, isso, gosta demais. Fazer questão dele, ele anda comigo direto, mas ele estuda. (C., pescador, 31 anos)

Conciliar os estudos e a pescaria neste contexto é uma responsabilidade difícil para os pais:

Não querem não, tem que tá conversando, tem que ter diálogo sempre com eles prá ver se eles voltam prá aula com vontade de estudar. Nem pode tá alimentando muito as esperanças que criança sabe como é que é né? For deixar... (C., pescador, 31 anos)

Além do conhecimento para saber o local onde cada peixe se encontra, diversas são as técnicas e apetrechos, artes, instrumentos de pesca, todas em acordo à espécie a ser capturada:

[...] se você quer pegar um Curimatá, você vai (às) 6 horas prá beira dum "lajeiro" desse, na época a gente ia, você via elas ali se ajeitando prá dormir né, $P$ ? A gente vê o banzeiro que elas tão, aí você conhece, olha aquilo ali é Curimatá. [...] Quando você quer pegar um pacu não, você vai atrás duma comida que ele come. Você chega numa flor, numa capoerana, numa samaúma, joga uma fruta, naquela cuia, aí você vê eles "coisando" lá, aí lá você cerca, bota malhadeira, pega eles. (R., pescadora, 43 anos)

[...] corvina, era na malhadeira né, cará, pacu também na malhadeira, curimatã era na tarrafa como lhe mostrei eu tenho as tarrafas aí, tem vários tipos de peixes que nós marisca na tarrafa e na malhadeira, agora o tucunaré só na "tela". (P., pescador, 64 anos) 
Pode-se observar que a pescaria se baseia também na preferência alimentar de cada peixe; sendo assim, os pescadores podem utilizar iscas como piabas vivas ou apenas fazer uso de seu conhecimento tradicional, ou seja, ficar observando as frutas e folhas caírem no rio:

[...] aí pacu a fruta tá caindo do igapó e o peixe tá batendo, sabe qual é o tipo do peixe, pacu é diferente que bate... (Seu C., pescador, 75 anos):

[...] lá está um pé ali, lá está aquelas moitas, que chama "sarobal"... dá goiaba... Pacu, matrinxã é só esses peixes que se alimentam... peixes pequenos se alimentam do lodo que dá embaixo... isso chama os tucunarés também, porque tem as piabinhas vão se alimentar e os tucunarés vão comer eles também, junta pra se alimentar. (P., pescador, 64 anos)

Além dos apetrechos de pesca propriamente ditos, são utilizados instrumentos de sondagem e reconhecimento, como a "tela" usada para verificar aonde é o poço, local preferencial de grandes bagres e mais fundo. Os pescadores utilizam-na para saber a profundidade e pescar trairão, pirarara e pescada:

[...] a Pirarara é no rio grande, tem as pontas dela, tem as pontas da ilha. A gente sabe qualé o local que a pirarara fica também... Fica no "poço", nos poços porque aonde tem essa ribanceira aqui, aqui é o poço. A pessoa encosta, joga a tela e sabe... a fundura a gente sonda, e sonda com a tela. Aí sabe qual poço dá a pescada, porque o poço que dá pescada, dá pirarara. (pescador Juruna, 62 anos,

Durante cinco dias acompanhando pescarias, em agosto de 2015, foram relacionadas 29 espé- cies de peixes, duas de quelônios, uma de jacaré, 14 localidades preferenciais de pesca, 12 micro-habitats e 13 artes de pesca, como mostram as tabelas a seguir.

TABELA 1 - Relação entre localidade, micro-habitats e artes de pesca.

\begin{tabular}{ccc}
\hline Localidades & Micro-habitats & Artes de pesca \\
\hline Arroz cru & Baixadas (baixões) & Arco e flecha \\
Caitucá (Kaituká) & Beiradão & Arpão \\
Cotovelo & Cerrado & Caniço \\
Felipe costa & Corredeira & Espinhel \\
Furo do Sabino & Lajeiro (pedras) & Malhadeira \\
Ilha das Meninas & Largão & Malhadeira ${ }^{\circ}$ 12 \\
Ilha do Bacabal & Poços & Tapuá \\
Jericuá & Ramada & Tarrafa \\
Landii & Remanso & Tarrafinha \\
Paratizão & Sarobal & Tela (anzol) \\
Paratizinho & Sequeiro & Tiradeira \\
Paty & Tronqueira & Vaqueta \\
Profiro & & Zagaia \\
Rama & & \\
\hline
\end{tabular}

FONTE: Trabalho de campo, 2015.

Nem todos os peixes puderam ser classificados em nível de espécies. Sendo assim, na Tabela 2 foram colocadas apenas as espécies que se pode identificar, para que não houvesse classificação indevida e negligente.

Esta classificação etnobiológica e científica foi baseada nos achados por Camargo \& Ghilardi Jr. (2009) e Vieira et al. (2009), para a mesma região do Xingu. 
TABELA 2 - Lista de peixes mencionados pelos pescadores na VGX. *Classificação incompleta.

\begin{tabular}{|c|c|c|}
\hline Peixes & Família & Espécie \\
\hline Acarizinho* & Loricariidae & \\
\hline Ariduia & Prochilodontidae & $\begin{array}{c}\text { Semaprochilodus } \\
\text { brama }\end{array}$ \\
\hline Arraia & Potamotrygonidae & $\begin{array}{c}\text { Potamotrygon } \\
\text { leopoldi }\end{array}$ \\
\hline \multicolumn{3}{|l|}{ Barbado* } \\
\hline Caratinga & Cichlidae & Geophagus altifrons \\
\hline Curvina & Sciaenidae & $\begin{array}{c}\text { Pachyurus } \\
\text { schomburgkii }\end{array}$ \\
\hline Curimatá & Prochilodontidae & Prochilodus nigricans \\
\hline Curupité & Characidae & Tometes sp. \\
\hline Fleixeira & Hemiodontidae & $\begin{array}{c}\text { Hemiodus } \\
\text { unimaculatus }\end{array}$ \\
\hline \multicolumn{3}{|l|}{ Jaraqui* } \\
\hline Matrinxã & Characidae & Brycon cephalus \\
\hline Pacu & Characidae & Myleus spp. \\
\hline Pacu branco & Characidae & Myleus torquatus \\
\hline Pacu Cadete & Characidae & Myleus schomburgkii \\
\hline Pacu Capivara & Characidae & Ossubtus xinguense \\
\hline $\begin{array}{l}\text { Pacu de } \\
\text { seringa* }\end{array}$ & Characidae & \\
\hline Pacu rosa* & Characidae & \\
\hline Pokomom & Auchenipteridae & Tocantinsia piresi \\
\hline Pescada & Sciaenidae & Plagioscion spp. \\
\hline \multicolumn{3}{|l|}{ Piaba* } \\
\hline Piau & Anostomidae & Leporinus spp. \\
\hline \multicolumn{3}{|l|}{ Pintado* } \\
\hline Piranha & Characidae & Serrasal spp. \\
\hline Pirarara & Pimelodidae & $\begin{array}{c}\text { Phractocephalus } \\
\text { hemiliopterus }\end{array}$ \\
\hline Surubim & Pimelodidae & $\begin{array}{l}\text { Pseudoplatystoma } \\
\text { fasciatum }\end{array}$ \\
\hline Traíra & Erythrinidae & Hoplias malabaricus \\
\hline \multicolumn{3}{|l|}{ Traíra Branca* } \\
\hline Trairão & Erythrinidae & Hoplias aimara \\
\hline Tucunaré & Cichlidae & Cichla melaniae \\
\hline
\end{tabular}

FONTE: Trabalho de campo 2015.

\section{Pescadores e efeitos socioambientais} sobre a pesca durante a construção da UHE Belo Monte

A partir de agora, iremos abordar algumas consequências advindas da construção da barragem, indicadas e vividas por moradores da VGX, com base no seu cotidiano já modificado e com um olhar sobre o futuro que anteveem. As consequências identificadas dizem respeito às restrições na navegação; ao desaparecimento de micro-habitats; à turbidez mineral; às explosões e luzes; e a conflitos por novas áreas de pesca.

\subsection{Restrições à navegação na Volta Grande do Xingu}

O rio é a principal via de locomoção destas populações tradicionais ou de pessoas que o utilizam para comercialização de produtos e/ou transporte de passageiros. Existe uma estrada chamada Trans-Assurini ou também Travessão da Ressaca, porém pouco utilizada pelos moradores da VGX. É reconhecida como muito perigosa e há moradores que jamais a utilizaram:

Porque a estrada é muito acidentada, muito, tem muitas ladeiras, tem muita, é, como é que diz, abismo dos lados né. Eu nunca andei, mas diz que tem né. Muitas ladeiras, já aconteceu de carro já descer nas ladeiras, capotar, matar gente, cair no abismo, coisa que toda cidade, todas estradas acontece né, mas só que essa daí, eu acho que é mais arriscada ela. (Pescadora, mulher de S., 36 anos)

Rapaz, o acesso todo tempo pra mim é por água, é por rio né, porque antes como todo mundo sabe era só pelo rio, agora que tem essa estrada que abriram não tá muito tempo, faz dois anos que foi aberto, então tem muito acesso por terra, mas eu não tenho loco- 
moção por terra, tenho locomoção por água, nosso transporte todo é por água. (P., pescador, 64 anos)

No período da seca, a navegação é difícil e perigosa, só navegando pescadores e pilotos experientes e em condições de navegabilidade favoráveis, especialmente com visibilidade que lhes permita identificar pedras, corredeiras e outros obstáculos. Durante a construção da barragem, verificou-se um crescente processo de turbidez mineral que dificultava a navegação, por vezes resultando em acidentes.

Porque antes a gente trafegava aqui na maior tranquilidade, a água era limpa, se via pedra, se via tudo, ai agora ficou do jeito é que nem você viu ali (rabeta virou), é dali pra pior, como eu lhe falei, é dali pra pior. (G., pescador, 83 anos)

Os pescadores afirmam que, após a barragem, com a redução da vazão, sobretudo no período de seca, será impossível trafegar na VGX:

Rapaz, o acesso não é bom não, né. Depois que nem você viu esse negócio aí, [...] tá raso aí né, fica batendo em pedra, uma hora acontece o que aconteceu (Rabeta virou com ele e família dentro), e é isso aí. (B., pescador, 25 anos)

\subsubsection{Navegação e o sistema de transposição}

Todavia, no que diz respeito às restrições à navegação, a consequência mais enfatizada por estes pescadores (e moradores) diz respeito à liberdade de ir e vir ou ao direito de chegar facilmente e sem barreiras em seu local de destino.

Com as obras do barramento do sítio Pimental, foi construído um sistema para "facilitar" a travessia das embarcações, denominado sistema de transposição de embarcações (Figura 5). De acordo com a cartilha explicativa lançada pela empresa em 2012, este sistema deveria garantir que todas as pessoas continuassem a navegar com segurança, tanto no período de construção da barragem como no período de operação da usina (Norte Energia, 2012). Ressalta-se que tal sistema já é definitivo - os moradores e quem precisar ir à VGX terão sempre que usar o sistema de transposição ou usar a Trans-Assurini.

Sem entrar nas deficiências técnicas do sistema (um substituto de eclusas que consiste num elevador que transporta embarcações e pessoas até o nível da água à montante, de onde se contorna o barramento por 700 metros de estrada, sobre um trator e a pé, respectivamente, até encontrar o rio), o que é chamado de transposição e deveria facilitar ou mitigar os problemas com a construção da barragem em relação à navegação é visto como um cerceador de liberdade e como vigilância e controle sobre o deslocamento de pessoas, animais e objetos. Em primeiro lugar, porque reduziu o número de canais tradicionalmente utilizados para a navegação. E em segundo lugar porque expõe, além da identificação de quem viaja, objetos e mercadorias que integram um amplo sistema de reciprocidade que interconecta moradores das vilas, das ilhas, das aldeias e da cidade. Como observam os moradores:

[...] porque de primeiro saía qualquer hora da noite eu ia bater em Altamira. porque fechou 4 canal nosso, foi 4, era da beira da terra; do Arroz Cru; tinha o do Pimental; tinha do furinho da bacabeira; e tinha o canal chefe, porque esses outros canais viajava só rabeta e o canal grande o chefe mesmo a voadeira né, por onde vocês vêm, nós vem agora. (P., pescador, 64 anos) 


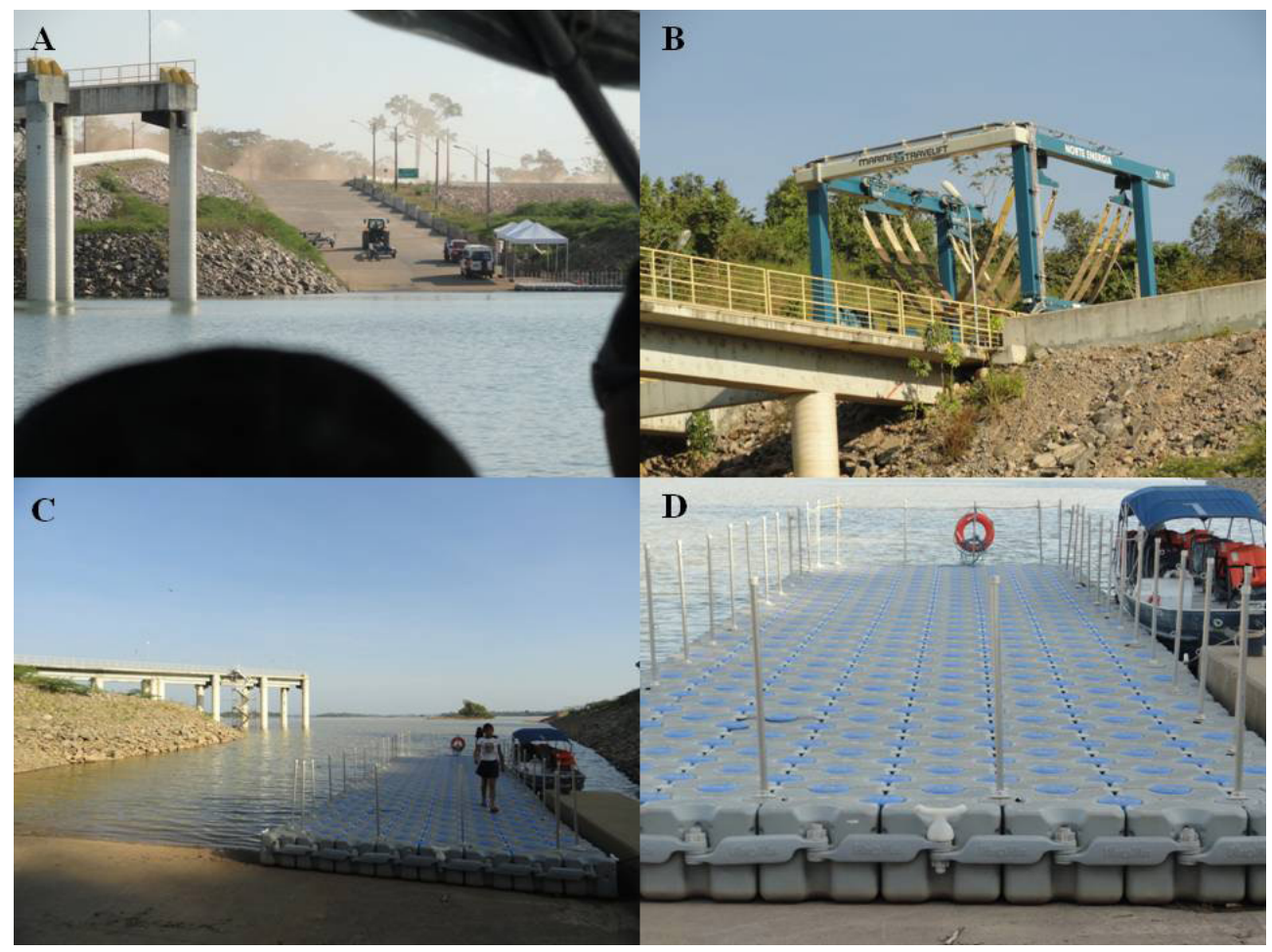

FIGURA 5 - Sistema de transposição construído para embarcações de até 35 t, visando atender ao fluxo entre a sede do município de Altamira e as localidades à jusante da barragem Pimental. A) Chegada, vista geral, B) Elevador para embarcações com até 35 t, C) Vista geral e D) Balsa para desembarque.

FONTE: Trabalho de campo, 2015. Fotos Yuri Silva.

[...] eu acho que devido aí a hidrelétrica acabou toda a privacidade, agora tem que passar todo mundo ali, tem que esperar, é um atrás do outro, demoram, acabou né sua liberdade que você tinha de ir e vir. Agora vocêtem de passar ali a hora, tem que esperar. Não é mais que nem, ai eu vou por ali eu vou por aqui eu sei de um caminho de um canalzinho ali eu varo por ali. Agora não, tudo é lá. (R., pescadora, 43 anos)

Não tá sendo bom né, porque ainda mais depois que eles começaram essa, como é que diz, é lá no, que eles pegam as embarcações (Transposição) né e colocam pro outro lado né, ai eles dizem que ia dar assistência, ia ficar melhor prá gente, aonde tem gente que espera lá por mais de 40 minutos prá poder ser atendido. (P., pescador, 64 anos)
[...] Aífica dificultoso né, prá quem já tinha o costume de ter o acesso de passar pelo rio sem precisar parar, sem atrasar, porque às vezes a gente vai com a família da gente e tem que esperar mais de 40 minutos, quase 1 hora prá poder passar esse barco pro outro lado, já é uma viagem..., além de atrasar a viagem da gente, é, às vezes tá com horário marcado de chegar, que muitos não tem casa em Altamira, tem que ir e vir, ai fica dificultoso né, pra quem faz esse trafegamento pra lá e pra cá. (Pescadora, mulher de S., 36 anos)

Ontem mesmo [...] nós chegamos lá passamos mais de hora, se duvidar passamos mais de hora né, que tinha faltado energia e ai [...] ficamos lá esperando, o cara foi ainda ligar que não tinha rádio também e custou chegar e a gente entra com criança, tudo é dificil. (pescador Juruna, 62 anos) 


\subsection{Micro-habitats - o sarobal}

Para os pescadores, uma das áreas significativas do rio é o chamado "sarobal", um tipo de vegetação que cresce sobre afloramentos de rochas graníticas no leito do rio Xingu e pertencem ao complexo geológico do Xingu; são terrenos instáveis, cobertos por vegetação herbácea com geófitos e/ou hidrófitos, ou seja, trata-se de vegetação pioneira de caráter edáfico que passa por processos deposicionais das areias de aluvião. Estas plantas suportam irradiação solar direta, temperaturas altíssimas, ciclos de cheia e seca e limitada consolidação de substratos (MCT/ MPEG, 2008; Camargo \& Ghilardi Jr., 2009).

[...] É porque na verdade é assim... São no inverno elas ficam no fundo, são plantas resistentes que o rio enche; na cheia do rio elas ficam todas cobertas né, ficam tudo submersa, mas no entanto não morre. $\mathrm{Na}$ baixada do rio, então, caem todas aquelas folhas. Ai quando o rio seca elas botam as folhas e flores de novo, porque elas são assim, as raizes são entranhadas entre aquela pouca areia que é encontrada nos pedrais da nossa região aqui, então elas se firmam ali entre as pedras e as areias, elas aguentam a correnteza da cheia do rio todo, tem plantas, isso é um sarobal feito disso no meio do rio... (R., pescadora, 43 anos)

Sarobal é esse mato que tem no meio do rio aí, esses lugares mais rasos que tem esse horror de pé de arvorezinha, essas coisas assim. (C., pescador, 31 anos)

Sarobal? É o goiabal, goiabal lá está ó (apontou para o rio); lá está um pé ali; lá está aquelas moitas, que chama sarobal, chama goiabal né? Porque dá goiaba, pessoal pra fora chama sarobal e nós chama goiabal, já tem duas palavras, sarobal e goiabal e é só uma coisa só porque ai tem as frutas né? (P., pescador, 64 anos)
A importância do "sarobal" (Figura 6) vai além da paisagística, pois ele é um componente importante tanto na vida dos ribeirinhos e indígenas que habitam a VGX quanto para toda a fauna e flora que ali reside ou depende dele:

Tucunaré, os peixes, que o sarobal tem muita fruta nele, o peixe consome né e ai esses lugares aí eles vão, acho que quase todo peixe né, depende deles. (Seu C., pescador, 75 anos)

O sarobal, o sarobal é uma mistura né? é o que a gente tem uma goiaba a goiaba braba que a gente fala, tem a goiaba, tem a caferana, tem o sarão, então isso tudo forma o sarobal, são misturados, são mistos, toda parte tem... são as frutas que dão umas frutinhas que os peixes comem, o piau, essa mistura dessas plantas que dá o sarobal, nosso sarobal aqui. (R., pescadora, 43 anos)

O "sarobal" é uma extensão da casa do ribeirinho, servindo como um local de encontro, lazer e principalmente trabalho, pois é muitas vezes destes afloramentos rochosos, repletos de árvores, arbustos e areia que se retira seu principal alimento.

Com a vazão reduzida, as árvores que dependem do ciclo de cheia e seca do rio só conhecerão a seca, comprometendo diretamente a perpetuação deste ecossistema, como observam os pescadores:

Vai acabar que esses lugares que eles vivem né tem muita água, sobrevive da água né, ai cortar, vai secar eles vão morrer, tendência é eles (sarobais) morrer, não tem jeito. (P., pescador, 64 anos)

Eu acho que não vai existir, porque vai secar, o lugar mais seco que tem, é esses lugar, aí devido eles tampar o rio, vai baixar e esse lugar vai secar. (Seu C., pescador, 75 anos) 


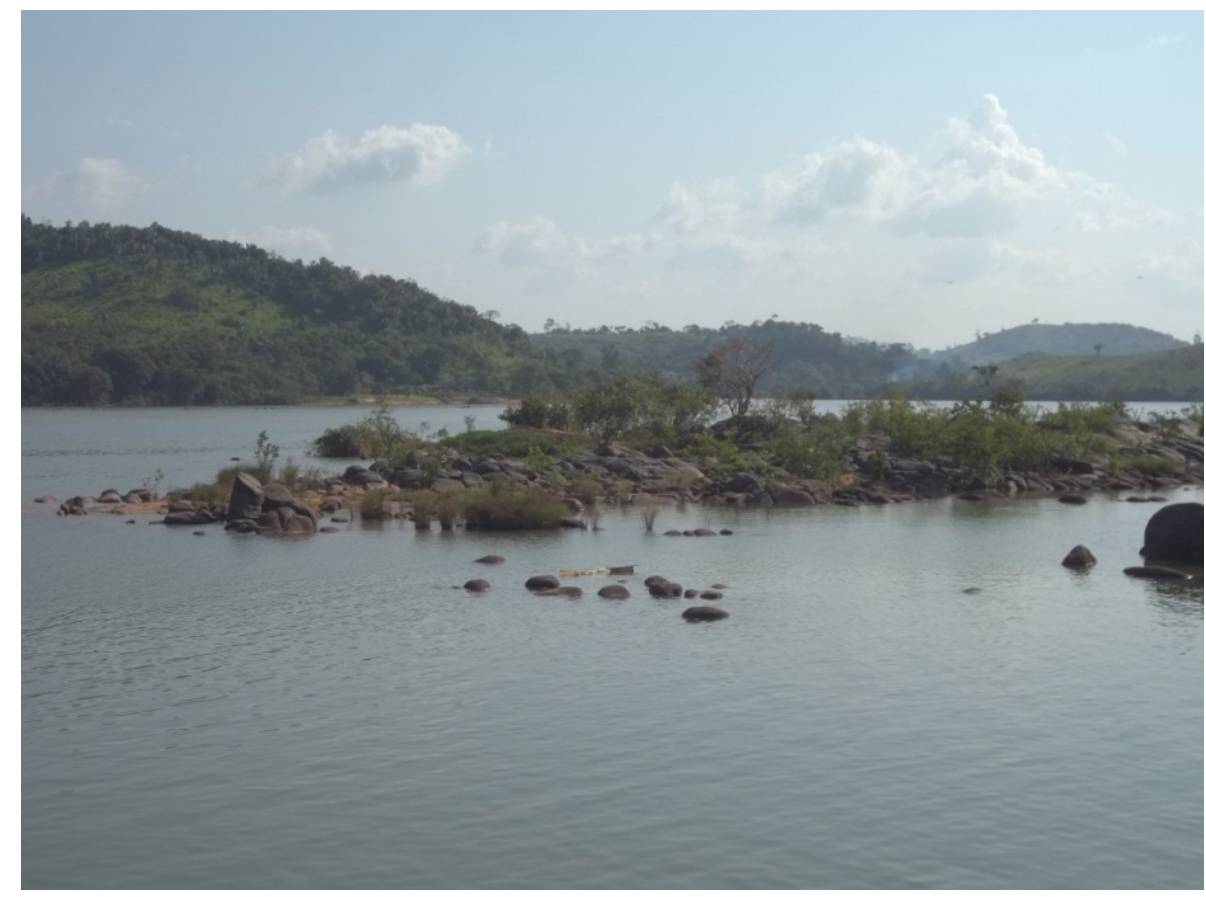

FIGURA 6 - Ecossistema denominado localmente "Sarobal". Vegetação que cresce sobre afloramentos de rochas graníticas no leito do rio Xingu. Local de encontro trabalho.

FONTE: Trabalho de campo, 2015. Foto Yuri Silva.

Com certeza porque ela é que nem falei pra você, elas são plantas, que elas ficam um periodo debaixo da água e outro periodo (verão) é agora que nem você tá vendo, tão tudo do lado de fora, tudo "florado", tudo já se preparando para dar suas frutas né, então como enchimento do lago eles vão ficar toda vida submerso (à montante de Pimental), então com certeza esse dai acabou da região. (R., pescadora, 43 anos)

A percepção da extinção destes ecossistemas se estende sobre suas consequências para os peixes e toda ictiofauna:

E os peixes? ai é uma boa pergunta, acabou a comida, acabou os peixes, acabou o pacu, o piau, acabou todo tipo de peixe que se alimenta daquelas plantas. (R., pescadora, 43 anos)
Rapaz, é assim, quando a gente pescava, assim que pegava, era quase todos os peixes que ficava, mas agora não fica mais é peixe nenhum agora. (Seu S., 83 anos)

\subsubsection{Outros micro-habitats}

Nesse processo, é iminente a perda de micro-habitats dos quais os peixes necessitam para sua alimentação e reprodução. Neste inverno (ano de 2015) não houve mais a "piracema", porque com o barramento - ainda parcial nesta fase de construção - as águas não entraram nos "baixões" das ilhas, não havendo a reprodução das espécies que realizam a "piracema": 
A construção de Belo Monte foi a extinção dos peixes do rio Xingu isso dai pode ter certeza tanto quem ficou pra cima quanto quem ficou pra baixo [...] Então eles subiam nessa época, novembro, dezembro, janeiro, quando dava abril, maio, junho eles desciam, a gente deduzia que eles desciam de novo, sem ova, tudo gordo, muito, muito, muito, acabou, isso daí digo pra você com experiência de vida de muitos anos de pescaria lá. Então acabou, esse ano (2015) já não existiu mais por que já mexeram o rio, estavam tampando o rio explodindo o rio, eles não passaram nem pra cima nem pra baixo. (R., pescadora, 43 anos)

Aqui pelo inverno pra nós não vai ter mais igapó, não vai ter, esse peixe vai sumir, como já de fato já, quando tem é muito pouquinho você vê o sinal deles no rio, não tem de jeito nenhum. E quando pega, não pega mais grande, pega bem miudinho. (Seu S., 83 anos)
[...] o pacu, pra nós aqui, ele vai ser eliminado daqui, porque o pacu ele não vive sem comer a flor e ele não vive sem o beiradão, e aqui não vai ter mais beiradão a partir do momento que isolarem essa água, não vai ter, vai ficar só os poço de lama, água lá em baixo,e o pacu não sobrevive a isso, como todo mundo sabe. (pescador Juruna, 62 anos)

Com o represamento total do rio e o desvio do mesmo, estes micro-habitats serão totalmente transformados, pois, com a vazão reduzida na VGX, muitos ficarão expostos, sem a alternância cheia/ seca do rio. Lugares como o "beiradão", "baixadas (baixões)", "lajeiro" e "tronqueiras de pau" (Figura 7) serão extintos.

O período da construção próximo à data de barramento do rio é o período em que se apresentam

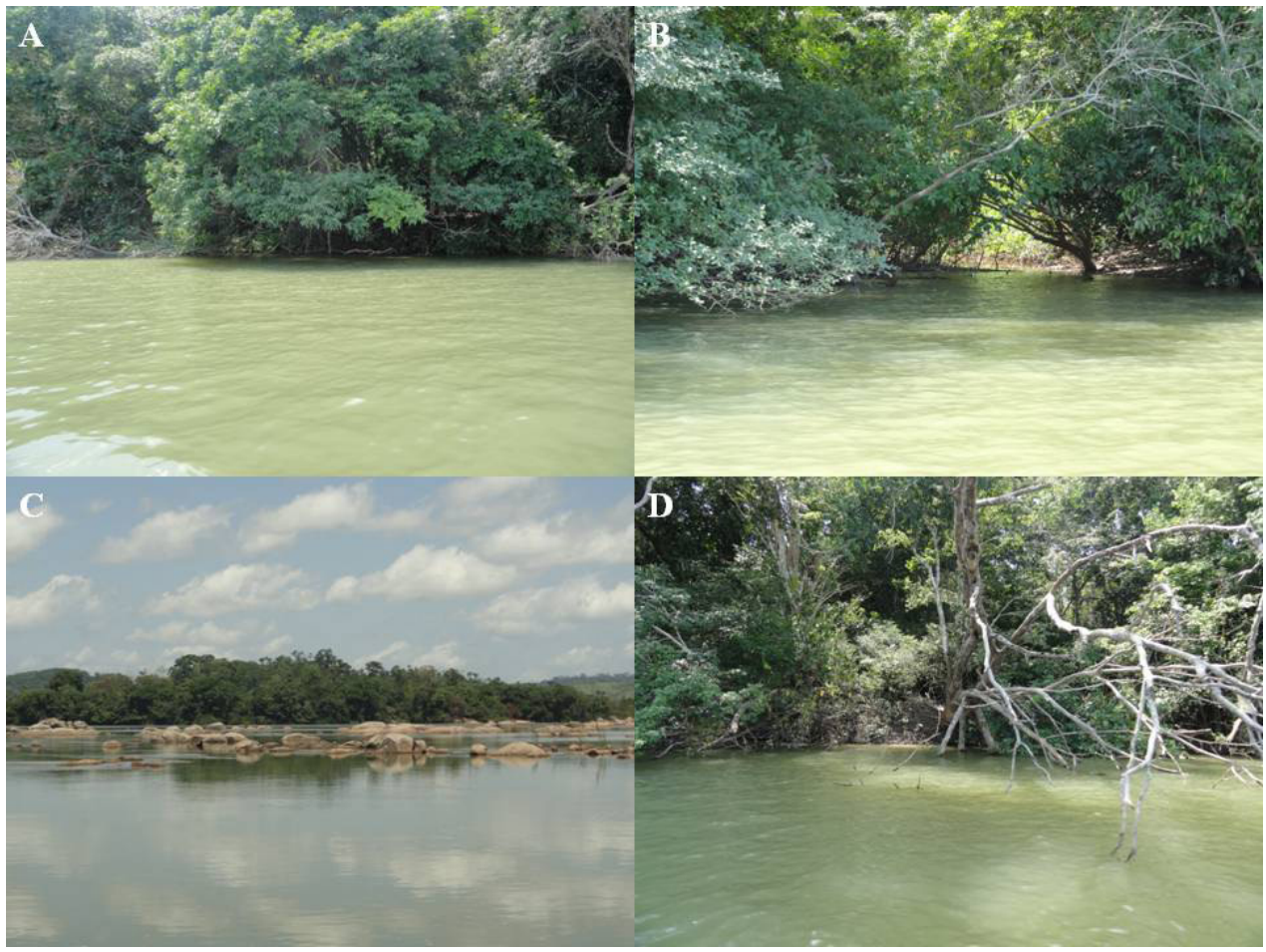

FIGURA 7 - Locais preferenciais de pesca e suas denominações locais. A) Beiradão; B) Baixadas; C) Lajeiro e D) Tronqueiras.

FONTE: Trabalho de campo, 2015. Fotos Yuri Silva. 
mais concretamente elementos sobre a situação futura. E, como tal, é marcado por ricas controvérsias entre os pescadores, mas, sobretudo, é marcado pela preocupação e pela angústia com um futuro desconhecido. A transcrição dos trechos de entrevista aqui apresentados não revela o tom de tristeza, as longas reticências, o olhar fixo no horizonte, assim como a raiva e a indignação e não raras vezes a lágrima que escorre incontrolável pelo rosto firme tostado pelo sol das pescarias. Constatação que advém não apenas do trabalho de campo, mas de uma disposição epistemológica para ouvir e entender e de um pressuposto metodológico de que a avaliação do efeito somente é plenamente inteligível a partir de quem o vivencia.

\subsection{Turbidez mineral: mudanças na cor e transparência da água}

Acima foi mencionada a turbidez mineral como um problema para a navegação. Ela, todavia, incide sobre outros domínios da vida de pescadores e moradores. Desde o início da construção da barragem, a turbidez mineral vem sendo motivo de preocupação, havendo períodos mais agudos que outros.

Uma vez com a gente teve uma reunião aí, o cara falando na água aí dizendo que essa água tava limpa. Teve limpa antes de ter "chupadeira" aqui, balsa, a água era limpa com 10 m enxergava o chão. Hoje em dia com $2 m$ ninguém enxerga.

Ele disse: - o senhor não pode dizer isso.

- Posso, eu nasci e me criei aqui dentro desse rio.

- Ah, mas a água tá limpa.

- Tá não, já foi limpa. (Seu C., pescador, 75 anos)
Após o fechamento do último trecho da barragem, na primeira semana de agosto de 2015, tal turbidez ficou ainda mais intensa e provocou grandes transformações no modo de vida destas populações:

O que aconteceu foi a água né, a água ficou só a lama aí, e ai o cara não teve acesso de nada... (C., pescador, 31 anos)

Piorou, piorou não, tá piorando todo tempo olhe ai (apontou para o rio) já sujou de novo a água. (P., pescador, 64 anos)

Uma coisa que eu nunca imaginei na minha vida que eu fosse ver, que eu desde menino nasci e me criei nessa região, que eu nunca imaginei que eu fosse ver, eu vi o rio da cor de uma lama um dia desse aqui. Era uma lama. Nunca nem passou pelo meu sentido de ver aquilo daquele jeito, entendeu? Ai uma coisa que marcou muito, o rio Xingu naquelas condições, pra mim marcou muito. (R., pescadora, 43 anos)

[...] aqui a gente usava água pra beber... Da cor de uma lama, não!! Era uma lama né, que tava descendo... Porque aqui a gente o rio pra, o ribeirinho usa o rio pra lavar, pra cozinhar, pra beber né, pra banhar. Ai devido à situação que teve, ainda tá sujo ainda, a água do rio ainda tá suja [...] Parece que é até por 90 dias né, ninguém pode consumir a água do rio, nem banhar, porque tem fatos de pessoas que tá dando micose, essa água não presta pra gente beber, tem que pegar água de outro lugar pra gente beber, tem que fazer poço. (P., pescador, 64 anos)

Em recente estudo, De Francesco \& Carneiro (2015) relataram que a água não é mais adequada para consumo humano, sendo que tais pescadores começaram a utilizar água do poço em suas pescarias. 


\subsubsection{A turbidez e a pesca}

A diminuição da visibilidade (Figura 8) traz consequências tanto para o pescador que vai em busca do recurso quanto do peixe que sai em busca do seu alimento: fez com que estas espécies procurassem águas mais claras, assim como os pescadores buscaram pontos de pesca mais visíveis:

Espero que se alguém pudesse ajudar né, fazer alguma coisa que melhorasse, por que é triste ver um rio que nem dessa forma que tá, só lama, o Xingu se tornou lama abaixo do barramento. (G., pescador, 83 anos)

[...] mas dos dias que aconteceu esses negócio aí (fechamento do último trecho do barramento), é por isso que eu te falo que o negócio do peixe tá fraco, que onde a gente pegava mais, não pega mais, os bicho desapareceu, não, peixe mesmo pra pegar aí tá difícil né, pra pegar tá difícil o negócio do peixe, o cara quase não pega mais. (pescador Juruna, 62 anos)
[...] nunca mais pus a malhadeira, outro dia coloquei só lama, enganchou. Só ver lodo. Outro dia me encabulei ali pro Landi. Cara, acostumado a andar ali todo dia quase, semana passada fui pra lá pra ver se pegava um peixe já tava suja a água, eu cheguei ali embaixo eu, ali na ilha da... Vou voltar... Ai fiquei pensando vou até ali no... peixe boiando no rio de jeito nenhum. Aí ia subindo e virei na ilha... Lá vem ele: - rapaz tá ruim de peixe, achava que a água tava limpa, botei seis malhadeiras e nada, uma enganchou penei pra tirar, não tirei; não podia nem cortar, lá sei o que tem embaixo, vou topar com uma arraia numa lama dessa. (Seu C., pescador, 75 anos)

Juntamente, perde-se a funcionalidade de alguns apetrechos de pesca, como o arco e flecha, o arpão ou a zagaia, agora não mais utilizados, pois, com a turbidez mineral, não se pode mais ver o peixe e deles se fazer uso. Assim também como a pesca ornamental, que dependia da visão e da destreza do pescador.

Vale lembrar que, além de espécies endêmicas como o pacu-seringa e capivara, que já eram consideradas espécies ameaçadas (Ibama, 2008a; 2008b),

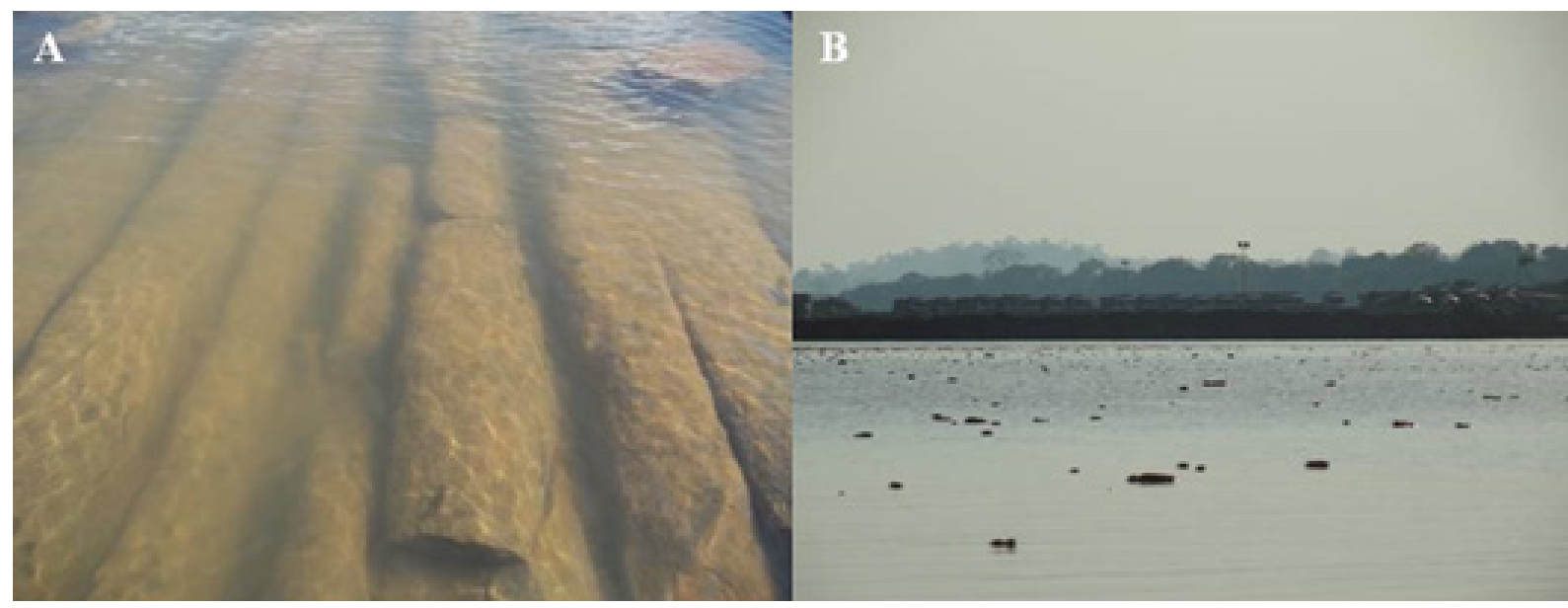

FIGURA 8 - Aspecto da turbidez da água do rio Xingu após o barramento, no sítio Pimental. A) Deposição de partículas nas rochas - Ilha da Fazenda, e B) Sólidos em suspensão próximo ao Sítio Pimental.

FONTE: Trabalho de campo, 2015. Fotos Yuri Silva. 
há uma porcentagem expressiva de espécies que ainda precisam ser identificadas e descritas para a região (Vieira et al., 2009). Outra consequência da construção de Belo Monte é que não se saberá o número exato de espécies residentes no rio Xingu.

\subsection{Explosão e luzes}

Como mostra o dossiê Belo Monte: não há condições para a licença de operação, realizado pelo ISA (2015): “As centenas de explosões de dinamite e as luzes dos potentes holofotes noturnos nos canteiros de obra levaram à descaracterização ou destruição física de locais antes abundantes em peixes, provocando inclusive, conforme relatos de pescadores da região, o sumiço de determinadas espécies". Os pescadores narram os efeitos destas explosões e luzes sobre a pesca:

[...] rapaz outro dia fui pegar umas piaba ali embaixo, botei farinha e nada de piaba, rapaz tá feio. Dei um lance lá, peguei três piabas. Pula fora, outro dia soltaram uma pra lá (explosão de dinamite) cada um pacuzão pulando no meio do rio aí. (Seu C., pescador, 75 anos)

Todo peixe a gente pega aqui, pegava né. É, cara, elas (piabas), tem delas que saem até da água, pula fora, jacaré, jacarezinho pula dentro d'água, cara... Outro dia eu ia passando lá 6h da manhã eles estavam, de dia, o fumacerão fica... a gente sente a coisa, o impacto. Um mal cheiro horrivel, cara [...] Basta dizer você teve aqui agora e viu o impacto que é causado por uma explosão dessa aí, coisas que a gente... Menino, ali fez rachar o cano do piso cara, eu não acreditava não, ele disse olha tu vai ver, tá abrindo cara, o impacto é tão forte que quando bate ele vai abrindo qualquer coisa. As panelas lá de casa colocada, uma hora tu vai ver, chega tremê. A gente sente, estrala cara (paredes). A gente vai falar, (eles dizem) não é nada isso é. Cansa de vir essas entrevistas aí, eles dizem isso. (C., pescador, 31 anos)
[...] essas dinamite que eles soltam lá tem vez que falta derrubar o barraco da gente rapaz. A gente vê, a gente tá no rio, quando tinha um restinho de peixe por aqui ainda, a gente tá no rio, quando eles soltam uma dinamite daquelas, você vê o peixe se assombrá moço. A piaba sai por cima d'água aí, doida, sem saber pra onde é que vai, com aquele "balançado", chega a canoa "banzera" assim, eu estou lhe falando, lhe digo e não é história não, lhe digo e provo. (Seu S., 83 anos)

A iluminação constante dos canteiros de obra e as frequentes explosões afugentam os peixes e é possível que também tenham alterado suas rotas migratórias (De Francesco \& Carneiro, 2015), como explica uma pescadora que morava na Ilha do Bacabal à montante da barragem:

[...] então quando eles começaram a explodir aqui, a mexer na região... na nossa região era região que não tinha muito pacu assim, não tinha assim muita espécie de peixe, então com pouco tempo olha você via grande quantidade... Quando eles começaram o trabalho deles aqui explodindo, aqueles caminhão, aquilo tudo, a gente começou a ver tartaruga lá, apareceu essas tartarugas, porque se você mora em uma localidade há muito tempo, você, quando aparece assim alguma coisa um jacaré grande, apareceu cada jacaré grande lá que não existia, então com certeza, eles fugiram, foram afugentados com as explosões com aquela barulheira de carro com tudo aquilo, movimento de gente, desmatamento derrubando tudo, acabando tudo, então com certeza eles foram embora pra lá, que lá era região mais calma, tava mais distante um pouco, entendeu? Então eles se foram afugentando pra cima e com certeza mais e mais adiante. (R., pescadora, 43 anos)

Outro efeito que os pescadores observam é decorrente da supressão de ilhas à montante da barragem, locais considerados de grande relevância para a perpetuação de algumas espécies, como é o caso dos quelônios da Amazônia. 


\subsection{Conflitos por áreas de pesca}

As transformações verificadas nas áreas de pesca, na reprodução da fauna aquática e no estoque de pescado têm motivado o deslocamento dos pescadores para outras áreas, mais distantes de seus locais tradicionais, que, além de implicar maiores gastos financeiros, mais horas e esforço de trabalho, têm resultado na invasão de áreas de pesca de outros pescadores, criando condições potenciais de conflito entre indígenas aldeados e pescadores (sobretudo não indígenas). Este é o caso, por exemplo, de toda $\mathrm{a}$ área que se estende da Terra Indígena por todo o trecho do rio que lhe margeia.

É a gente aprende muitas coisas com eles, eles com a gente, só que tem aquele detalhe, eles têm a área deles demarcada pela FUNAI lá, demarcada, área fulano de tal, só entra gente que é conhecido, outro de fora não entra pra pescar, se vier, por exemplo, um pescador lá de Altamira e descer pra dentro da área da Muratu que é a aldeia dos índios ali, uns colegas nossos, chegar lá ele não pesca, se for possivel pegá, prende tudo do cara, entendeu? (B., pescador, 25 anos)

O conflito pode ser iminente, rompendo uma relação que ao longo dos anos vem se estabilizando como uma relação de reciprocidade - pescam juntos, trocam conhecimentos, respeitados limites e regras.

\subsection{Desuso e perda do conhecimento tradicional}

Outra consequência evidente, que começa a ser vivida ainda durante a construção da barragem, é o desuso, a não transmissibilidade e, preveem os pescadores, a consequente perda do conhecimento tradicional.
Meu amigo, de fato eu vou the explicar bem aqui ó. Esses nossos filhos que são pequenos, essas crianças que tão vindo agora, esses meninos não vão ter o privilégio que a gente teve de aprender nada não, isso ai eu lhe garanto. Não tem mais aonde pular não. (Seu S., 83 anos)

Pra conhecer, pra viver o que a gente já viveu, pode esquecer. A cultura da nossa região, do nosso povo, nosso lugar, isso ai já se acabou parceiro. A derrota da região é essa dai, entendeu? (Pescadora, mulher de S., 36 anos)

Se for crescendo e tiver alguma água né por aqui, porque ninguém não sabe, e nem peixe né, porque se tiver peixe, quem sabe não aprende, mas pelo que eu estou vendo não vai chegar a acontecer não. (B., pescador, 25 anos)

Sobre a transmissibilidade do conhecimento tradicional, foi possível constatar ainda a preocupação, sobretudo dos mais velhos, com a autoridade associada a este conhecimento. Em entrevista realizada com um pescador/morador com mais de 60 anos, nascido no local, ele se perguntava: "-Como os meus netos vão acreditar no que eu digo? Como eu vou dizer que o rio Xingu era assim, que eи conhecia todo lugar, que não tinha lugar que eu não ia... o que eu vou dizer? Esse velho ai não sabe é nada...", concluía ele sobre a provável reação de seus netos sobre um conhecimento que perdera lugar e, consequentemente, que perdera propriedades que lhe são intrínsecas - experimentação e prova, por sua vez, fundamentos da oralidade.

Correlata aos efeitos socioambientais durante a construção da barragem, verifica-se também a busca por alternativas econômicas. No caso em análise, desenham-se iniciativas de transição de produtores polivalentes (Furtado, 1993) para agricultores de terra firme. Como boa parte dos pescadores artesanais na Amazônia, estes produ- 
tores combinavam pesca, agricultura, extrativismo vegetal, coleta e artesanato, por meio de um arranjo econômico, familiar e territorial, cuja identidade profissional acaba por obscurecer. No caso específico destas duas localidades, havia ainda a atividade garimpeira, sazonal, também suspensa. Esta combinação pesca e garimpo ou agricultura e garimpo é encontrada em várias regiões da Amazônia, desde os anos 1950 (Magalhães, 2002).

Estes pescadores começaram, então, a aumentar a produção agrícola familiar, como um lastro para a segurança alimentar ameaçada e para o desaparecimento das condições socioambientais de produção de sua principal atividade econômica.

Aí então até isso, estamos aprendendo a viver de outra maneira, que de pesca não dá mais e a outra profissão que ele (marido) era garimpeiro não tem mais. Porque é assim: eles pescavam, ai depois passava um tempo no garimpo. Ai agora estamos mexendo com negócio da colonia, é o outro meio de sobrevivência né. É o que todo mundo tá fazendo aqui depois que essa barragem chegou é tentando sobreviver, modificando o modo de vida da gente, porque aqui a maioria dependia da pesca... Tentar sobreviver de outras maneiras, peixe desapareceu... Então tá todo mundo tentando sobreviver de outra maneira, que nem muitos aqui tá fazendo o que a gente tá fazendo, que nós não tinha o costume de trabalhar na roça, mas tá tentando sobreviver, plantando... (Pescadora, mulher de S., 36 anos)

Outra forma de viver, roça. Aqui, se você não se envolver com roça, você não vive. É sobre isso daí que aconteceu. Norte Energia, falou que não ia tirar ninguém, então os peixes tava se acabando, que nem tá se acabando né, e ai o meio de sobreviver daqui mais pra frente vai ser isso daí, eu acho que é isso ai. (R., pescadora, 43 anos)

\section{Controvérsia entre pescadores e a Norte Energia}

Os efeitos socioambientais acima apontados foram objeto de averiguação da Norte Energia, mediante acordo realizado em setembro de 2014 entre a Norte Energia e as Colônias de Pescadores de Altamira e de Vitória do Xingu.

No período entre setembro de 2014 e abril de 2015, depois de seguidas denúncias dos pescadores, foi realizado por aquela empresa um levantamento que, dentre outros objetivos, visava avaliar "a percepção dos pescadores quanto a impactos na atividade pesqueira" (Norte Energia, 2015, p. 4), considerando não apenas a região lócus desta pesquisa, mas também todo o trecho do futuro reservatório situado à montante do sítio Pimental.

Foram consideradas no rol de "percepções", dentre as aqui apresentadas: a turbidez da água; a diminuição de peixes; a alteração de rota migratória; e os conflitos.

Este relatório conclui que:

Os impactos relatados, sejam eles sobre a comunidade íctica, sobre a pesca, sejam sobre a qualidade da água e alterações de vazão do rio, não foram confirmados com a interpretação dos dados disponíveis [...] não há até o momento [...] aumento da turbidez no rio Xingu e em seus tributários localizados próximos ao empreendimento [...] mesmo que os pescadores infiram sobre [...] impactos à pesca oriundos da implantação do empreendimento, dificuldades de pesca com malhadeira e anzol, entre outros, os resultados do projeto não indicam perda de CPUE (rendimento pesqueiro) nos locais próximos ao empreendimento [...] a avaliação minuciosa de impactos apontados pela população que está em contato frequente com o rio Xingu [...] indicam que não há comprometimento ou prejuízos às atividades de pesca. (Norte Energia, 2015, p. 49 e 50). 
Em setembro de 2015, o Instituto Socioambiental interveio na controvérsia com a produção de um "Atlas dos impactos da UHE de Belo Monte sobre a pesca", visando "insistir na legitimidade, pertinência e relevância dos conhecimentos tradicionais das comunidades amazônicas" (De Francesco \& Carneiro, 2015, p. 5) e demonstrando que "diversos impactos negativos sobre as comunidades de pescadores foram detectados ainda durante a fase de instalação do empreendimento" (De Francesco \& Carneiro, 2015).

O estudo finaliza contestando a conclusão acima mencionada apresentada pela Norte Energia e afirma: "A interpretação da Norte Energia, no sentido de que a atividade pesqueira não tem sido prejudicada [...] só se faz possível quando a análise dos dados coletados nos programas de monitoramento parte de pressupostos incorretos sobre o ambiente e sobre a dinâmica de seu uso por esses grupos sociais" (De Francesco \& Carneiro, 2015, p. 62). As autoras referem-se, por exemplo, à exclusão da pesca de subsistência e de importantes pesqueiros da coleta de dados efetuada pela empresa.

Em fevereiro de 2016, o IBAMA reconheceu as denúncias dos pescadores e submeteu à dúvida os relatórios apresentados pela Norte Energia (ISA, 2016).

Embora não seja objeto deste artigo analisar a controvérsia, apresentar os principais termos do debate nos aponta, por um lado, que os estudos sobre efeitos socioambientais de grandes barragens mobilizam epistemologias diversas, requerem metodologias específicas e arcabouço institucional capaz de absorvê-los - inclusive para que o reconhecimento das consequências não fique restrito ao período pós-construção.

\section{Considerações finais}

Observamos ao longo deste texto que os efeitos socioambientais das grandes barragens não se restringem apenas ao período de operação. Durante a construção, o fluxo de máquinas, equipamentos e pessoas destinados à construção e seu entorno incide sobre territórios e recursos naturais que são condição para a reprodução social e econômica de povos e comunidades. O conhecimento tradicional acumulado faculta a apreensão de transformações sutis no ambiente, incluindo o comportamento de peixes e demais integrantes da fauna aquática, alterações na turbidez da água, na vegetação e outras, assim como de mudanças nas relações sociais. Deste modo é, também, um poderoso aliado para a antevisão de transformações e suas consequências.

Do ponto de vista sociotécnico e político, resulta importante alertar para a desconsideração deste conhecimento e especialmente para a desconsideração do sentido vivido, isto é, do sentido atribuído à transformação ocorrida. O gradiente de sua magnitude não pode estar fora do contexto no qual ocorre. Assim, seja a magnitude do conflito entre pescadores, seja a abrangência da turbidez, seja a amplitude da explosão, deveriam ter como unidade de medida o sentido vivido.

Do ponto de vista institucional e político, é necessário que haja reconhecimento da epistemologia de produção e reprodução do conhecimento tradicional, com canais competentes para que as avaliações produzidas a partir dele sejam igualmente consideradas.

Os efeitos da destruição de ambientes e relações vividos durante a construção de Belo Monte são contundentes e palpáveis para quem vive e precisa do rio Xingu e necessitam ser adequadamente incorporados aos manuais que avaliam impactos. 
Mas devem, sobretudo, ser publicizados para a sociedade, a quem cabe avaliar o tamanho da destruição que está disposta a aceitar para viabilizar esta tecnologia de geração de energia.

\section{Agradecimentos}

Este texto é resultado de pesquisas desenvolvidas no âmbito dos projetos Hidrelétricas, Sociedade e Ambiente, no Estado do Pará, e Agricultura Fa-

\section{Referências}

Ab'Saber, A. N. A Amazônia: do discurso à práxis. São Paulo: EDUSP, 1996.

Arruda, R. "Populações tradicionais" e a proteção de recursos naturais em Unidades de Conservação. Ambiente \& Sociedade, II(5), 1999.

Bernard, H. R. Research methods in anthropology: qualitative and quantitative approaches. Altamira Press, Lanham, 2002.

Brasil. Decreto n. 6.040, de 7 de fevereiro de 2007. Diário Oficial da República Federativa do Brasil, Poder Executivo, Brasília, DF, 7 fev. de 2007.

Camargo, M.; Ghilardi Jr., R. Entre a terra, as águas e os pescadores do médio rio Xingu: uma abordagem ecológica. 1. ed. Belém-PA, 2009.

Camargo, M.; Carvalho Júnior, J.; Estupiñan, R. A. “Ecorregiões Aquáticas Xingu-Tapajós”: peixes comerciais da ecorregião aquática Xingu-Tapajós. Centro de Tecnologia Mineral. Ministério da Ciência, Tecnologia e Inovação. Coordenação de Processos Minerais - COPM. 2012. p. 175-192.

Cardoso, E. S. Vitoreiros e Monteiros: ilhéus do Litoral Norte Paulista. 1994. 78 f. São Paulo, Dissertação (Mestrado) - Universidade de São Paulo, 1996.

Cardoso, E. S. O vento, o fundo, a marca: diálogos sobre a apropriação da natureza no universo pesqueiro. In: Diegues, A. C. (Org.). Enciclopédia Caiçara, o olhar do miliar e Desenvolvimento Agroambiental, na Amazônia, apoiados pela Fundação Amazônia Paraense de Amparo à Pesquisa (FAPESPA) e pelo Conselho Nacional de Desenvolvimento Científico e Tecnológico (CNPq), respectivamente. Agradecemos aos pescadores que nos acolheram na Ilha da Fazenda e na Ressaca; às Colônias de Pescadores de Vitória do Xingu (Z-12) e de Altamira (Z-57), especialmente a seus presidentes; e a Cristiane Carneiro, que nos proporcionaram a expedição realizada em 2015.

pesquisador. v. 1. São Paulo-SP: Hucitec-NUPAUB-CEC/ USP, 2004. p.133-164.

Carvalho Júnior, J. R. Composição e distribuição da ictiofauna de interesse ornamental do Estado do Pará. Belém, Dissertação (Mestrado em Ciência Animal) - Universidade Federal do Pará, UFPA, 2008.

Carvalho Júnior, J. R. et al. Sobre a pesca de peixes ornamentais por comunidades do rio Xingu, Pará - Brasil: relato de caso. Boletim do Instituto de Pesca, 35(3), 521-530, 2009.

Carvalho Júnior, J. R. et al. O conhecimento etnoecológico dos pescadores Yudjá, Terra Indígena Paquiçamba, Volta Grande do Rio Xingu, PA. Tellus, 11(21), 123-147, jul./ dez. 2011.

CNDH - Conselho Nacional dos Direitos Humanos. Relatório da missão do CNDH em relação à população atingida pela implementação da UHE Belo Monte. Brasília/DF, 2015.

Cunha, M. C.; Almeida, M. W. B.; Populações tradicionais e conservação ambiental. In: Capobianco, J. P.; Ribeiro, J. P. et al. (Org.). Biodiversidade na Amazônia brasileira: avaliação e ações prioritárias para a conservação, uso sustentável e repartição de benefícios. São Paulo: Instituto Socioambiental, 2001.

De Francesco, A.; Carneiro, C. Atlas dos impactos da UHE Belo Monte sobre a pesca. São Paulo: ISA, 2015.

Diegues, A. C. Pescadores, camponeses e trabalhadores do mar. São Paulo: Ática, 1983. 
Furtado, L. G. Pescadores do rio Amazonas: um estudo antropológico da pesca ribeirinha numa área amazônica. Belém: Museu Paraense Emílio Goeldi, 1993.

IBAMA - Instituto Brasileiro do Meio Ambiente e dos Recursos Naturais Renováveis. Instrução Normativa IBAMA 203, de 22 de outubro de 2008. Brasília, 2008a.

IBAMA - Instituto Brasileiro do Meio Ambiente e dos Recursos Naturais Renováveis. Instrução Normativa IBAMA 204, de 22 de outubro de 2008. Brasília, 2008b.

ISA - Instituto Socioambiental. Dossiê Belo Monte: não há condições para a licença de operação. Altamira: ISA, 2015.

ISA - Instituto Socioambiental. Cinco anos após início da instalação de Belo Monte, Ibama reconhece impactos na pesca. Disponível em: <https://www.socioambiental.org/ pt-br/noticias-socioambientais/cinco-anos-apos-inicio-da-instalacao-de-belo-monte-ibama-reconhece-impactos-na-pesca>. Acesso em: 25 fev. 2016.

Magalhães, S. B. Tempo e trajetórias: reflexões sobre representações camponesas. In: Hébette, J.; Magalhães, S.; Maneschy, M. C. (Org.). No mar, nos rios e na fronteira: faces do campesinato no Pará. Belém: Edufpa, 2002. p. 233-274.

Magalhães, S. B. Lamento e dor: uma análise socioantropológica do deslocamento compulsório provocado pela construção de barragens. Belém, Tese (Doutorado) - Programa de Pós-Graduação em Ciências Sociais, UFPA; Paris 13, École Doctorale Vivant et Sociétés, 2007.

Magalhães, S.; Sanz, F. Impactos sociais e negociações no contexto de grandes barragens: reflexões sobre conceitos, direitos e (des)compromissos. Fragmentos de Cultura, 25(2), 2015.

Mauss, M. Essai sur le don: forme et raison de l'échange dans les sociétés archaïques in Sociologie et anthropologie. Paris: PUF, 1997.

MCT/MPEG. Relatório final de vegetação. Descrição e análise da flora da região do médio-baixo rio Xingu. 2008.

Medeiros, H. F. Avaliação de impactos do projeto de aproveitamento hidrelétrico de Belo Monte sobre a vida selvagem, incluindo implicações socioeconômicas. In: Magalhães, S. B.; Hernandez, F. Análise crítica do estudo de impacto ambiental do aproveitamento hidrelétrico de Belo Monte. Belém, 2009. Disponível em: <https://www.
socioambiental.org/banco_imagens/pdfs/Belo_Monte_Painel_especialistas_EIA.pdf $\% 20 \% 20>$. Acesso em: 16 jan. 2016.

Molina, J. Questões hidrológicas no EIA Belo Monte. In: Magalhães, S. B.; Hernandez, F. Análise crítica do estudo de impacto ambiental do aproveitamento hidrelétrico de Belo Monte. Belém, 2009. Disponível em: <https://www. socioambiental.org/banco_imagens/pdfs/Belo_Monte_Painel_especialistas_EIA.pdf $\% 20 \% 20>$. Acesso em: 16 jan. 2016.

Nascimento, G. C. C. Pesca artesanal em "currais": um enfoque etnoecológico. 2012. 157 f. João Pessoa, Dissertação (Mestrado em Desenvolvimento e Meio Ambiente) - Universidade Federal Paraíba/PRODEMA, 2014.

Norte Energia. Sistema de transposição de embarcações e as comunidades indigenas UHE Belo Monte. 1. ed. Altamira: Anticorp Designer, 2012.

Norte Energia. Avaliação sobre as percepções dos pescadores da Volta Grande do Xingu sobre possiveis impactos localizados decorrentes da UHE Belo Monte. Relatório técnico. Superintendência dos Meios Físico e Biótico. Diretoria Socioambiental (RT_SFB_No004_PIPS_01-062015_Leme-Praxis_v03). Altamira/PA, 2015.

Sevá, A. O. F. Tenotã-mõ: alerta sobre as consequências dos projetos hidrelétricos no rio Xingu. 1. ed. São Paulo, 2005.

Santos, G. M.; Santos, A. C. M. Sustentabilidade da pesca na Amazônia. Estudos Avançados, 19(54), 165-182, fev.-abr. 2005.

Silva, Y. Y. P. da. "Nasci e me criei nesse rio": análise dos impactos na pesca artesanal na Volta Grande do Xingu durante a construção de Belo Monte. Belém, Monografia, UFPA, 2015.

SUDAM - Superintendência para o Desenvolvimento da Amazônia. Atlas Climatológico da Amazônia Brasileira. Belém, PA, Brasil: SUDAM/PHCA, 1995. 125 p.

Vieira, M. E. G. et al. EIA-RIMA AHE Belo Monte estudo socioambiental componente indígena: Terra Indígena Paquiçamba. Relatório Técnico-Científico, 2009.

Usina Belo Monte. Disponível em: $<$ http://norteenergiasa. com.br/site/portugues/usina-belo-monte/>. Acesso em: 21 out. 2015. 
WCD - World Commission on Dams. Dams and development: A new framework for decision-making. Report of the World Commission on Dams, 2000. Disponível em:
$<$ http://www.unep.org/dams/WCD/report.asp $>$. Acesso em: 06 jan. 2016. 